\title{
A Bíblia: Escritura Sagrada para judeus e cristãos
}

\author{
Waldecir Gonzaga ${ }^{1}$
}

\section{Resumo}

Tendo presente esta edição da Revista CREatividade sobre Cristianismo, que traz como título "No seguimento de Jesus Cristo", iluminado pela letra/poema "andar com fé eu vou, que a fé não costuma falhar", este artigo versa sobre o Cânon Bíblico das Sagradas Escrituras, que compreende o Antigo Testamento, comum à tradição judaico-cristã, e o Novo Testamento, da tradição cristã, comum para católicos, ortodoxos, protestantes, evangélicos, pentecostais e neopentecostais. A intenção é ajudar a refletir sobre a Bíblia, livro que contém os textos sagrados da tradição judaico-cristã. Na prática, a Bíblia não é um livro apenas e sim uma grande biblioteca, formada por cada um de seus muitos livros, que podem ser lidos no conjunto ou separadamente. O termo Bíblia, usado no singular, em português ou em qualquer língua moderna, deriva da língua grega: tá Bíblia (os livros), sendo um plural neutro de ho Biblos, que significa o livro. Ela é, ainda hoje, o livro mais traduzido, mais vendido e mais lido no mundo, constituindo o maior best-seller da história da humanidade. A Bíblia é obra de um Divino Autor e literatura do Povo Eleito chamado a ser o Povo da Aliança. Ela foi escrita em diferentes épocas e por autores diferentes que, em sua maioria são desconhecidos. Ademais, ela tem arranjo e número de livros diferentes, dependendo da tradição religiosa.

Palavras-chave: Bíblia. Sagradas Escrituras. Cânon Bíblico. Antigo Testamento. Novo Testamento.

\section{Introdução}

A Bíblia é uma coleção de escritos, chamados também Sagradas Escrituras ou Livros Sagrados. A Bíblia Católica é diferente da Bíblia Hebraica, que é mais breve e assim chamada porque foi escrita em hebraico (e uma pequena parte em aramaico), contendo 39 livros. A Bíblia Hebraica também é chamada de TaNaK, um acróstico formado pelas inicias de cada uma das três palavras que formam seus três blocos: Torah (Lei, instrução), Nebi'îm (Profetas) e Ketubîm (Escritos).

A Bíblia Católica tem quatro divisões e conta com 46 livros para o Antigo Testamento (AT), contendo os livros [proto]canônicos e os

\footnotetext{
${ }^{1}$ Doutor em Teologia Bíblica pela Pontifícia Universidade Gregoriana, Roma. Diretor e Professor de Teologia Bíblica do Departamento de Teologia da PUC-Rio. E-mail: <waldecir@hotmail.com>, Currículo Lattes: http://lattes.cnpq.br/9171678019364477 e ORCID ID: https://orcid.org/0000-0001-5929-382X
} 
livros [deutero]canônicos: Pentateuco (Torah: 5), Históricos (16), Sapienciais (7) e Proféticos (18), e mais os 27 livros do Novo Testamento (NT), também divididos em quatro blocos: evangelhos (4) e Atos dos Apóstolos (1); cartas Paulinas (13) e carta os Hebreus (1); cartas Católicas/Universais (7); e Apocalipse de João (1). A divisão entre AT e NT existe só para cristãos, mas não para os judeus, que contam apenas com os livros do AT. O NT é obra de cristãos e para cristãos. Aqui sugerimos conferir a obra de I. Mazzarolo, A Bíblia em suas mãos (2000), visto que ela traz uma breve introdução a todos os livros da Bíblia: AT e NT.

A Bíblia Protestante tem quatro divisões e conta com 39 livros para o AT, contendo apenas os livros [proto]canônicos: Pentateuco (Torah: 5), Históricos (12), Sapienciais (5) e Proféticos (17), e mais os 27 livros do NT, na mesma divisão que a Bíblia católica: evangelhos (4) e Atos dos Apóstolos (1); cartas Paulinas (13) e carta os Hebreus (1); cartas Católicas/Universais (7); e Apocalipse de João (1). Assim sendo, a diferença entre católicos e protestantes encontra-se em relação aos AT e é igual no que diz respeito ao NT.

O autor da Bíblia é Deus, que é o inspirador; e também podemos dizer que é o homem, uma vez que Deus se serviu de pessoas que Ele foi escolhendo ao longo da História da Salvação e Ihes foi revelando aquilo que Ele queria que fosse escrito e registrado para a posteridade, para nos transmitir a Sua vontade e aquilo que Ele queria revelar em vista da salvação do ser humano.

\section{A Inspiração, a revelação e a inerrância da}

\section{Palavra de Deus}

Muito se tem discutido e refletido sobre os termos inspiração, revelação e inerrância em relação à Bíblia, Palavra de Deus. Queremos aqui apenas esclarecer o significado dos termos, no sentido de ajudar a compreendê-los e a provocar ulteriores estudos, uma vez que temos literatura neste campo e indicamos as obras de $\mathrm{E}$. Arens, $A$ Bíblia sem mitos (2012: 213-300); de L. Agostini Fernandes, A Bíblia e a sua Mensagem (2010: 53-65); V. Mannucci, Bíblia, Palavra de Deus (2008: 41-62.139-153) e de W.J. Harrington, Chave para a Bíblia (2002: 27-41) que trazemos em nossa bibliografia final, sendo introdutórios e de fácil leitura. 
a) Inspiração é o ato pelo qual Deus capacita certos homens, utilizando-se dos meios, também humanos, para fazer-Se conhecido através da linguagem humana, e se refere ao movimento particular do Espírito de Deus. Deus é o inspirador e o ser humano é o inspirado, aquele que recebe a inspiração divina. Neste sentido, em termos gerais, a ideia da Inspiração está associada a uma graça particular ou um especial sopro divino que determinadas pessoas receberam para falar, registrar, agir ou escrever determinadas coisas em nome de Deus (do grego: hagiógrafos: hágios = santo, e gráfo = escrevo), a fim de comunicar a Sua vontade aos seres humanos, que são os destinatários da Palavra de Deus. A inspiração define Deus e os hagiógrafos como verdadeiros autores da Sagradas Escrituras. E ela não é exclusiva da fé judaica e cristã. Pelo contrário, egípcios, assírios, gregos, persas, romanos etc., também acreditam na "comunicação inspirada pela divindade" à humanidade. O que difere é a forma de entender a modalidade e o alcance da inspiração em cada uma dessa tradições, inclusive no interior da tradição judaico-cristã. Aliás, assim como os judeus e os cristãos defendem que a Bíblia é inspirada, os muçulmanos têm a mesma ideia em relação ao Alcorão, livro sagrado do Islã. Além disso, a visão de inspiração sobre o texto sagrado diverge na visão do fundamentalista, que não admite nenhum tipo de "erro", nem sequer de ciência, e aquele que admite que a inerrância diz respeito às questões de fé e salvação e não nas questões de ciências empíricas, por exemplo.

b) Revelação é o ato pelo qual Deus entra e age na história para falar aos homens como amigo, pelos fatos e palavras, e se refere à verdade manifestada na história. $\mathrm{Na}$ base da religiosidade está a aceitação de que a divindade cultuada por um determinado povo pode e manifesta a sua vontade a pessoas escolhidas, que agem como mediadores entre a Divindade e a Humanidade. O diferencial e específico da concepção judaico-cristã reside justamente em considerar alguns escritos como inspirados e normativos para a vida da Comunidade que, uma vez aceita, determina o povo como povo da Revelação e o texto como Sagrado, como texto revelado ou que contém a revelação de Deus, a saber, aquilo que Deus quer dizer para seus filhos e filhas, em vista da salvação. Deus foi se dando a conhecer nos fatos e acontecimentos da vida de Israel, o povo da Aliança, e tudo isso foi sendo registrado para as gerações futuras. 
Neste sentido a revelação é a manifestação de Deus na vida e história de seu povo. Deus se manifestou muitas vezes e continua a se manifestar na vida de cada um ainda hoje. As Sagradas Escrituras aceitas, elas registraram a revelação de Deus em alguns momentos da história, uma vez que ela não foi escrita de uma única vez e nem em curto tempo. Pelo contrário, ela demandou muito tempo e um processo longo para ser escrita e aceita definitivamente como Livro Revelado. O fato de que a revelação tenha sido compreendida é porque ela foi fértil e produziu efeito na vida do Povo de Deus. Caso contrário, seria estéril e infrutífera. Os acontecimentos foram sendo compreendidos e interpretados, para depois serem registrados como tal, contendo a revelação divina para o ser humano e foi capaz de continuar estabelecendo o diálogo entre o ser humano e Deus ao longo da história, após ter sido registrada e aceita como Palavra de Deus mesmo, como o é nos dias atuais.

c) Inerrância: significa ausência de erro ou que algo não tem erro. A inerrância é um predicado da Bíblia e está intimamente ligado à sua autoridade e à sua inspiração. Duas são as correntes acerca da inerrância bíblica: 1) Inerrância absoluta: os fundamentalistas entendem a inerrância em seu sentido absoluto, ou seja, a total ausência de qualquer tipo de erro. Eles se apoiam sob o fato de que Deus é o autor da Bíblia e por isso não pode haver nenhum erro na Bíblia, de nenhum gênero ou espécie. Assim sendo, os fundamentalistas se recusam a entrar em contato e diálogo com os estudos críticos da Bíblia. Com isso, eles demonstram falta de conhecimento do tipo e gênero de literatura que temos na Bíblia, que não é, por exemplo, das ciências empíricas. 2) Inerrância limitada: é a posição daqueles que defendem a inspiração conceitual, não verbal, e aceitam a exatidão da Bíblia para questões de salvação e ética e não para questões das ciências empíricas. Neste sentido, a inspiração divina não impediu que os autores bíblicos cometessem "erros" de natureza histórica ou científica, uma vez que estes não afetam nossa salvação eterna. A Bíblia não é inerrante em tudo quanto diz, mas é infalível em tudo quanto ensina a respeito de fé, moral e costumes. A verdade salvífica, essa é aquela de que a Bíblia trata, do encontro do ser humano com Deus e de Deus com o ser humano.

\section{As línguas bíblicas e o material de escrita}


Os livros da Bíblia, em sua grande maioria, foram escritos em hebraico, parte em aramaico e parte em grego para o Antigo Testamento, e grego para o inteiro Novo Testamento. A primeira e mais antiga tradução do AT foi para o grego, entre os anos 250 a.C. a 150 a.C, chamada até hoje de Septuaginta ou Setenta (LXX), e a primeira tradução do AT e do NT completos para o latim, foi a Vulgata de Jerônimo, final do séc. IV d.C.

$\mathrm{Na}$ época em que a foram escritos os Livros Sagrados ainda não havia a Prensa, que foi inventada por Johannes Gutenberg no séc. XV de nossa era, e a Bíblia foi escrita em Tabuinhas de Cerâmica (argila cozida em forno), em Papiro (planta originária do Egito) e Pergaminho (couro de carneiro curtido).

A Bíblia foi vivida e contada pelos pais aos filhos, transmitida oralmente antes de ser escrita. Mas a tradição escrita durou mais ou menos 1.000 anos. Para o AT, a escrita começou por volta de 950 a.C. e terminou por volta do ano 50 a.C. Para o NT a escrita começou por volta do ano 50 d.C. e terminou por volta do ano 100 d.C. A fase da Escrita vem após a fase da Tradição Oral, quando a Bíblia era transmitida de pai para filho, de geração em geração.

Outro dado que precisamos ter presente e levar em consideração é que todos os exemplares originais dos escritos tanto do AT como do NT "se perderam" e que seus textos chegaram até nós unicamente por meio de cópias de cópias, uma vez que o material era muito frágil e precisa ser sempre copiado e recopiado para ser mantido em boas condições de uso. Além disso, no que diz respeito aos Manuscritos que temos à disposição, e são muitos, mais de seis mil já catalogados, eles são divididos em vários grupos, que são colocados segundo o tipo, família e distribuição geográfica.

A língua hebraica é uma língua semítica e consonantal, que não possui vogais, e o texto bíblico hebraico que temos remonta ao período do II Tempo (515 a.C. a 70 d.C.) até o ano 100 d.C., quando todas as comunidades judaicas o teriam adotado como forma textual final e que os Massoretas vocalizaram durante os séculos VI ao IX d.C. Portanto, o Texto Massorético que possuímos hoje (hebraico, também chamado de Leningradense) já conta com mais de mil anos de história. É a partir desse texto que hoje são feitas as edições da Bíblia Hebraica e mesmo as traduções modernas, inclusive para o mundo cristão, no tocante ao AT. 
No que diz respeito ao NT, escrito totalmente em língua grega, uma língua com consoantes e vogais, nós temos uma vasta gama de Manuscritos que são trabalhados por vários estudiosos no mundo hoje, na tentativa de recuperar o texto original dos escritos do Novo Testamento. Mas essa tarefa é realmente árdua e de grande responsabilidade, pois se trata de resgatar os primeiros escritos do cristianismo.

Se não bastasse isso, ainda temos a questão dos textos chamados apócrifos ou extracanônicos, que ficaram fora do cânon, que são numerosos tantos para o AT (52) como para o NT (88), onde encontramos muita literatura edificante e bastante próxima aos textos que foram escolhidos pela Igreja e deixados como canônicos, genuínos, inspirados e revelados. Para tanto, sugerimos conferir o texto de J. F. FARIA, Bíblia Apócrifa, a outra face do cristianismo (2009). Esse foi realmente um processo longo e difícil para a lgreja, que o concluiu tão somente por volta do final do séc. IV d.C. Sobre este tópico sugerimos conferir a obra de J. Konings, A Bíblia, sua origem e sua leitura (2011), que nos apresenta aspectos introdutórios da caminhada da "confecção" da Bíblia judaico-cristã.

\section{Traduções da Bíblia}

Ao longo dos séculos a Bíblia foi, e continua sendo ainda hoje, traduzida em muitos idiomas a partir do hebraico, do aramaico e do grego. A primeira tradução da Bíblia Hebraica foi para o grego, a chamada LXX, realizada por 72 anciãos, em Alexandria, no norte do Egito, entre os anos 250 a 150 a.C., que mais tarde se tornou o texto do Antigo Testamento para a Igreja e a base do seu Cânon.

A tradução latina chamada Vulgata foi feita por Jerônimo, no final do séc. IV d.C., tendo como base o texto hebraico/aramaico para os livros da Bíblia preservados no cânon judaico hebraico palestinense, contendo 39 livros, e o texto judaico helênico alexandrino, com livros escritos em língua grega, para os demais livros aceitos pela Igreja, os sete chamados deuterocanônicos. As Bíblias em linguagem moderna são traduzidas dos textos nas línguas originais: hebraico, aramaico e grego, para o AT, e grego para o NT. Para saber de onde determinada Bíblia foi traduzida, normalmente basta ler a informação que a mesma traz logo em suas primeiras páginas. 
O AT já falava de uma divisão tripartítica para a Bíblia, como lemos no Prólogo do tradutor do livro do Eclesiástico (versículos 1.8-10.2425): a Lei, os Profetas, e os outros Escritos dos antepassados. De tal forma que podemos constatar que a Bíblia já tinha esta ordem deste a.C. Também nos ajuda o testemunho dos elogios que Bem Sirac faz à história dos antepassados no mesmo livro do Eclesiástico, em seus capítulos 40 a 49: "Elogiemos os homens ilustres, nossos antepassados, em sua ordem de sucessão" (Eclo 44,1)

A divisão da Bíblia em capítulos foi concluída por volta de 1220, pelo Cardeal Estevão Langton, Arcebispo de Cantuária, na Inglaterra. Ele foi professor na Sorbone de Paris e faleceu no ano de 1228. E a divisão em versículos foi revisada pelo frade dominicano Santo Pagnini, italiano, em 1528. E foi o tipógrafo Roberto Etienne, um protestante, em 1555, quem concluiu a obra de revisão e divisão, em vista da impressão tipográfica.

Enfim, o ser humano colaborou, entre muitas coisas, com o uso da própria linguagem escrita. Por isso, dizemos sempre que a Bíblia é uma coleção de 73(66) livros, chamados também Livros Sagrados ou Sagradas Escrituras, escritos por inspiração de Deus, e que trazem a Palavra de Deus, em palavras humanas, revelada para a salvação do ser humano. O autor ou redator humano de cada livro chama-se hagiógrafo ou escritor sagrado, pois Deus é o autor por excelência.

\section{Os critérios para a Formação do Cânon Bíblico do AT e do NT}

Embora possamos afirmar que os principais critérios para a formação do Cânon do Bíblico tenham sido a pessoa de Jesus, como norma suprema, e a pregação oral dos apóstolos, juntamente com a vida da comunidade e seu uso litúrgico, como pontos de referência no que diz respeito aos critérios que foram sendo levados em consideração para a aceitação dos livros presentes tanto no AT como no $\mathrm{N}$ ), percebemos que houve uma progressão nos mesmos até que se chegasse a fechar o Cânon Bíblico como o temos hoje. Aliás, devemos supor que sucedeu algo bem normal: quando a tradição oral começa a se tornar suspeita e incontrolável, impõe-se a necessidade de escritos que transmitam fielmente essa tradição.

Não se pode falar de aceitação de um livro apenas a partir de um critério e sim do conjunto de critérios, pois admitir como decisivo a aceitação de apenas um único critério poderia gerar graves erros. Não 
foi um critério sozinho e sim o conjunto dos critérios que deu base para se chegar às escolhas que foram sendo feitas, passo a passo, dos livros tanto para o AT como para o NT. Estes critérios podem ser resumidos na sequência que trazemos abaixo, como, aliás, encontramos no texto da Pontifícia Comissão Bíblica (1994: 113-115).

a) Apostolicidade e pregação apostólica: No que diz respeito ao texto do AT, foi aceito aquele texto que foi recebido pelos apóstolos como sendo Palavra de Deus, comum ao mundo judaico, pois todos eram judeus, ainda que alguns fossem judeus da diáspora, mas sempre judeus. E o texto mais usado e aceito para o AT foi o da versão da Bíblia Grega, a LXX, até mesmo porque era a língua mais corrente e usada naquele momento. No que diz respeito ao NT, levou-se em conta se era um texto escrito por um apóstolo ou atribuído a ele, como fruto de sua pregação, que entrou como garantia de autenticidade dos escritos que circulavam pelas comunidades cristãs primitivas, visto terem sido testemunhas oculares do mestre, e que dão ao texto o que hoje chamamos de imprimatur apostólico. Interessante perceber os passos nesta direção e ver que foi se formando uma espécie de núcleo de escritos apostólicos, como que uma seleção de obras que continham o "coração" do ensinamento apostólico, obras estas que foram revelando e confirmando cada vez mais o conteúdo da fé apostólica. É importante que também tenhamos presente que tal critério não foi tão simples de ser praticado, pois muitos apócrifos eram obras pseudoepígrafas e isso gerava problemas no discernimento. Estes últimos eram textos atribuídos a apóstolos, como vários dos livros apócrifos que não entraram no Cânon Bíblico. Os diversos grupos se pautavam por isso e geravam discussões e divisões na Igreja. Isso acabou fazendo com que algumas igrejas aceitassem alguns livros e recusassem outros (MANNUCCI, 2008: 241-242).

b) Regra de Fé (Regula fidei / Ortodoxia): a partir da problemática do cânon reduzido ou cânon mutilado de Marcião, que não hesitou em recusar todos os livros do AT e tirar do NT tudo o que ele considerava alheio à mensagem cristã, criando um cânon próprio do NT, com apenas Lucas e 10 cartas paulinas (144 d.C.) e do Movimento Montanista (172 d.C.), a Igreja foi delineando o valor de uma reta ortodoxia na transmissão dos textos e de seus conteúdos, bem como no conjunto de todos os livros já aceitos ou não pelas chamadas Igrejas locais. Em reação a Marcião, vários autores vão defender o AT 
como Palavra de Deus e igualmente os livros do NT. Por exemplo, no séc. II, em reação a Marcião temos Justino de Roma e sua defesa da regula fidei (100-165 d.C.). A Diatéssaron de Taciano (120-180 d.C.) reconstrói a vida de Cristo a partir dos quatro Evangelhos, tendo como base o Evangelho de João. Irineu de Lyon (130-202 d.C.) defende que o Evangelho é Tetramorfo, além de defender o cânon longo do NT. Clemente de Alexandria (150-217) vai contra Marcião e defende os quatro Evangelhos e um cânon longo do NT. Tertuliano, no norte da África (160-220), vai contra o cânon mutilado de Marcião e defende os quatro Evangelhos e o cânon amplo. O cânon do Fragmento Muratoriano (170 d.C.) defende igualmente os quatro Evangelhos e o cânon amplo do NT. Isso, levando em consideração que nem todos já citem todos os livros bíblicos do NT, como teremos a partir do séc. IV. Além disso, estes autores defenderam o AT como Palavra de Deus, igualmente rebatendo Marcião, que recusou o inteiro AT.

c) Antiguidade: o tempo foi passando e foram surgindo novos escritos, muitos dos quais foram considerados apócrifos (extracanônicos), e ficaram fora do Cânon Bíblico. Juntamente com os critérios de "apostolicidade" e de "regra da fé" havia outro necessário para garantir que um texto era ou não canônico; ou seja: a "antiguidade", pois tinha que ser de uso e aceitação comum para o AT e de autoria de um apóstolo e do período dos apóstolos para o NT. Mesmo assim, tudo indica que alguns textos do NT tenham escapado à regra e são apenas de atribuição, pois foram escritos após a morte do apóstolo ao qual foi atribuído, a exemplo da Segunda Carta de Pedro, hoje datada por volta do ano 130 d.C. Aliás, os dois primeiros séculos parecem ter sido realmente "um período de furiosa atividade literária", com muita produção neste campo, onde alguns textos entraram para o cânon e outros não, como é o caso dos muitos textos apócrifos tanto do AT (52 livros ficaram fora) como do NT (88 livros ficaram fora). Como a autoridade devia ser depositada sob um dos apóstolos e eles já tinham morrido, é óbvio que foi se estabelecendo o critério da antiguidade como forma de autenticidade, visto que as coisas iam se multiplicando e sendo falsificadas. Assim se levou em conta se um texto era mais antigo ou mais recente para também ser aceito ou recusado. Mesmo assim, alguns textos que contavam com a atribuição apostólica acabaram entrando no Cânon, mesmo tendo sido 
escrito após a morte do referido Apóstolo; e um número considerável ficou de fora (FARIA, 2009: 63-80).

d) Uso litúrgico e adaptabilidade nas igrejas locais: por fim, visto que os textos do AT foram recebidos da tradição judaica e que os textos do NT foram escritos para comunidades específicas, mas que começaram a circular pelas diversas comunidades cristãs orientais e ocidentais, é óbvio que o uso litúrgico e catequético nas diversas comunidades teve forte impacto na aceitação ou não dos textos que foram entrando no cânon ou eram recusados e deixados de fora, pois contava muito se o texto era capaz de alimentar ou não a vida pessoal e eclesial do cristianismo nascente, equacionando eficiência e fidelidade à proclamação cristã primordial. As primeiras gerações de fiéis foram lendo e encontrando nos escritos do AT e do NT "uma fonte de força espiritual", que depois foi ratificada pela autoridade eclesiástica, confirmando a escolha tradicional do uso dos textos nas várias comunidades cristãs. Se a aprovação dos textos contou com o imprimatur apostólico também o fez com o imprimatur da própria comunidade da lgreja que ia usando o texto. Também contaram as distâncias geográficas e culturais das diversas Igrejas bem como as diferentes orientações teológicas dos grandes centros cristãos de pensamento da época (principalmente Roma, Antioquia da Síria, Éfeso e Alexandria). Enfim, contaram e muito as decisões eclesiásticas oficiais, visto ser fruto da Igreja e de sua intuição religiosa, ainda que estas apareçam somente no final do século IV, quando também já temos a tradução da Vulgata latina para o Ocidente. A própria a história da manufatura dos códices tem seu influxo: não é pura casualidade que somente no século IV se conseguiu o aperfeiçoamento técnico suficiente para fabricar códices grandes com muitas folhas, tornando assim possível colecionar juntos vários livros, até então copiados em pequenos códices soltos. Sobre este tópico, sugerimos consultar a nossa obra: W. Gonzaga, Compêndio do Cânon Bíblico (2019), sendo possível ver a abundância de dados, desde o período inicial do cristianismo.

\section{Livros das Bíblias Hebraica, LXX, Católica e Protestante}


A seguir, na tabela, podemos conferir os livros do AT e do NT, tratados como Escritura pelos primeiros escritores cristãos. Na coluna que se refere à Bíblia da LXX, indicamos alguns títulos de livros em itálico, para facilitar a compreensão de como eles são tidos por nós hoje: algunas são tidos como apócrifos (Apóc.) e outros nós consideramos [deutero]canônicos (Deut.), dentre os livros do AT; e os sem nenhuma indicação são os [proto]canônicos, aceitos pelos judeus e cristãos (católicos e protestantes). Para os 27 livros do NT, hoje temos uma mesma e única ordem entre católicos e protestantes e são indicados apenas nas duas colunas, referentes a eles.

No início da Reforma Protestante houve uma recusa tanto de 7 livros [deutero]canônicos do AT (Tobias, Judite, 1 e 2 Macabeus, Sabedoria, Eclesiástico e Baruc) como de 7 livros [deutero]canônicos do NT (Hebreus, Tiago, Judas, 1 e 2 João, 2 Pedro e Apocalipse). O termo não indica prioridade de conteúdo e sim cronologia de aceitação, ou seja, que os [proto]canônicos foram aceitos num primeiro momento e que os [deutero]canônicos foram aceitos num segundo momento. Mas ambos são canônicos: proto e deutero canônicos. Aliás, os 7 livros [deutero]canônicos do NT já foram novamente aceitos pelos protestantes como sendo canônicos, enquanto que os 7 livros [deutero]canônicos do AT ainda não foram aceitos pelos protestantes, mas continuam sendo aceitos tanto pelos católicos, como pelos ortodoxos.

O texto em língua hebraica, também chamado de Texto Massorético, é o texto judeu curto, igualmente chamado de Cânon Palestinense, por ter sido escrito pelos judeus da Palestina, enquanto que o texto da $L X X$, tradução do hebraico para o grego e mais os livros escritos diretamente em língua grega, é o texto judeu mais longo, também chamado de Cânon Alexandrino, traduzido pelos judeus em Alexandria, no norte do Egito. O Cristianismo nascente usou o texto da LXX em seus primórdios, desde o tempo de Cristo, e é ele o texto mais citado do AT no NT. Aliás, para a citações do AT no NT nós temos um uso de aproximadamente $90 \%$ retirados da versão da LXX e não diretamente do texto Hebraico.

O texto da Bíblia Católica, que segue a ordem e o número de livros do texto da LXX, menos os apócrifos, tem tanto os livros do texto Hebraico como os livros escritos diretamente em grego, que se encontram na LXX. Como podemos conferir a seguir, com exposição 
dos quatro arranjos ou ordens dos livros do Cânon Bíblico, tanto do AT como do NT, há uma diferença entre os católicos e os protestantes, que veio da Bíblia da LXX. A Bíblia da LXX, além dos livros [proto]canônicos, escritos em hebraico e aramaico e que foram traduzidos para o grego, também traz alguns livros [deutero]canônicos e alguns tidos como apócrifos ou extracanônicos, abaixo indicados pela abreviação do termo e entre parênteses, escritos diretamente em grego. Aqui indicamos todos os livros de cada tradição religiosa. Chamamos a atenção para a tradução da LXX, que traz 53 livros para o AT, com a tradução dos [proto]canônicos (do hebraico/aramaico para o grego), com os [deutero]canônicos (deut.) e o que hoje são tidos como apócrifos (apóc.), escritos em grego, visto ela foi a Bíblia que o cristianismo usou em seus primórdios, influenciando enormemente a decisão do Cânon Bíblico na Igreja. Para melhor entender a riqueza e a diversidade do material sobre o Cânon Bíblico, indicamos a nossa obra W. Gonzaga, Compêndio do Cânon Bíblico (2019), seja pelos muitos textos ao longo da história do cristianismo, seja pela abundância de dados, inclusive com várias tabelas ilustrativas, como a que trazemos abaixo.

\begin{tabular}{|c|c|c|c|}
\hline \multicolumn{4}{|c|}{ Ordem dos livros nas Bíblias judaico-cristãs } \\
\hline Hebraico (39 livros) & LXX (53 livros) & Católica (73 livros) & $\begin{array}{c}\text { Protestante }(66 \\
\text { livros) }\end{array}$ \\
\hline Torah/Lei & Pentateuco/Lei & Pentateuco & Pentateuco \\
\hline Gênesis & Gênesis & Gênesis & Gênesis \\
\hline Exxodo & $\hat{E} x o d o$ & $\hat{E} x o d o$ & Exxodo \\
\hline Levítico & Levítico & Levítico & Levítico \\
\hline Número & Número & Número & Número \\
\hline Deuteronômio & Deuteronômio & Deuteronômio & Deuteronômio \\
\hline \multicolumn{4}{|l|}{ Nebiîm/Profetas } \\
\hline $\begin{array}{c}\text { Profetas } \\
\text { Anteriores }\end{array}$ & Históricos & Históricos & Históricos \\
\hline Josué & Josué & Josué & Josué \\
\hline Juízes & Juízes & Juízes & Juízes \\
\hline 1 Samuel & Rute & Rute & Rute \\
\hline 2 Samuel & $\begin{array}{l}1 \text { Reis [= } 1 \\
\text { Samuel] }\end{array}$ & 1 Samuel & 1 Samuel \\
\hline 1 Reis & $\begin{array}{l}2 \text { Reis }[=2 \\
\text { Samuel] }\end{array}$ & 2 Samuel & 2 Samuel \\
\hline 2 Reis & 3 Reis [= 1 Reis] & 1 Reis & 1 Reis \\
\hline $\begin{array}{c}\text { Profetas } \\
\text { Posteriores }\end{array}$ & 4 Reis [= 2 Reis] & 2 Reis & 2 Reis \\
\hline Isaías & $\begin{array}{l}1 \text { Paralipômenos } \\
\text { [= 1Crônicas] }\end{array}$ & 1 Crônicas & 1 Crônicas \\
\hline Jeremias & $\begin{array}{l}2 \text { Paralipômenos } \\
\text { [= 1Crônicas] }\end{array}$ & 2 Crônicas & 2 Crônicas \\
\hline
\end{tabular}




\begin{tabular}{|c|c|c|c|}
\hline Ezequiel & 1 Esdras (apóc.) & Esdras & Esdras \\
\hline Os Doze Profetas & $\begin{array}{l}2 \text { Esdras (= } \\
\text { Esdras e Neemias } \\
\text { juntos) }\end{array}$ & Neemias & Neemias \\
\hline Oseias & $\begin{array}{l}\text { Ester [com } \\
\text { fragmentos do } \\
\text { grego, 10,4-16] }\end{array}$ & Tobias (deut.) & \\
\hline Joel & Judite (deut.) & Judite (deut.) & \\
\hline Amós & Tobias (deut.) & Ester & Ester \\
\hline Abdias & $\begin{array}{l}1 \text { Macabeus } \\
\text { (deut.) }\end{array}$ & 1 Macabeus (deut.) & \\
\hline Jonas & $\begin{array}{l}2 \text { Macabeus } \\
\text { (deut.) }\end{array}$ & 2 Macabeus (deut.) & \\
\hline Miqueias & $\begin{array}{l}3 \text { Macabeus } \\
\text { (apóc.) }\end{array}$ & & \\
\hline Naum & $\begin{array}{l}4 \text { Macabeus } \\
\text { (apóc.) }\end{array}$ & Saíenciais/Poéticos & Sapienciais/Poéticos \\
\hline Habacuc & Poéticos & Jó & Jó \\
\hline Sofonias & $\begin{array}{l}\text { Salmos (com o SI } \\
151 \text { ) }\end{array}$ & Salmos (150) & Salmos (150) \\
\hline Ageu & Odes (apóc.) & Provérbios & Provérbios \\
\hline Zacarias & Provérbios & Eclesiastes & Eclesiastes \\
\hline Malaquias & Eclesiastes & $\begin{array}{l}\text { Cântico dos } \\
\text { Cânticos }\end{array}$ & Cântico dos Cânticos \\
\hline Ketubin/Escritos & $\begin{array}{l}\text { Cântico dos } \\
\text { Cânticos }\end{array}$ & Sabedoria (deut.) & \\
\hline Salmos & Jó & Eclesiástico (deut.) & \\
\hline Jó & Sabedoria (deut.) & & \\
\hline Provérbios & $\begin{array}{l}\text { Siracida } \\
\text { (Eclesiástico) } \\
\text { (deut.) }\end{array}$ & Profetas Maiores & Profetas Maiores \\
\hline Rute & $\begin{array}{l}\text { Salmos de } \\
\text { Salomão (apóc.) }\end{array}$ & Isaías & Isaías \\
\hline $\begin{array}{l}\text { Cântico dos } \\
\text { Cânticos }\end{array}$ & $\begin{array}{l}\text { Profetas } \\
\text { Menores }\end{array}$ & Jeremias & Jeremias \\
\hline Eclesiastes (Coélet) & Oseias & Lamentações & $\begin{array}{l}\text { Lamentações de } \\
\text { Jeremias }\end{array}$ \\
\hline Lamentações & Amós & Baruc (deut.) & \\
\hline Ester & Miqueias & Ezequiel & Ezequiel \\
\hline Daniel & Joel & Daniel (14) & Daniel (12) \\
\hline Esdras-Neemias & Abdias & & \\
\hline 1 Crônicas & Jonas & Profetas Menores & Profetas Menores \\
\hline \multirow[t]{11}{*}{2 Crônicas } & Naum & Oseias & Oseias \\
\hline & Habacuc & Joel & Joel \\
\hline & Sofonias & Amós & Amós \\
\hline & Ageu & Abdias & Obdias \\
\hline & Zacarias & Jonas & Jonas \\
\hline & Malaquias & Miqueias & Miqueias \\
\hline & Profetas Maiores & Naum & Naum \\
\hline & Isaías & Habacuc & Habacuque \\
\hline & Jeremias & Sofonias & Sofonias \\
\hline & Baruc $[=\mathrm{Br} 1-5]$ & Ageu & Ageu \\
\hline & $\begin{array}{l}\text { Lamentações de } \\
\text { Jeremias }\end{array}$ & Zacarias & Zacarias \\
\hline
\end{tabular}




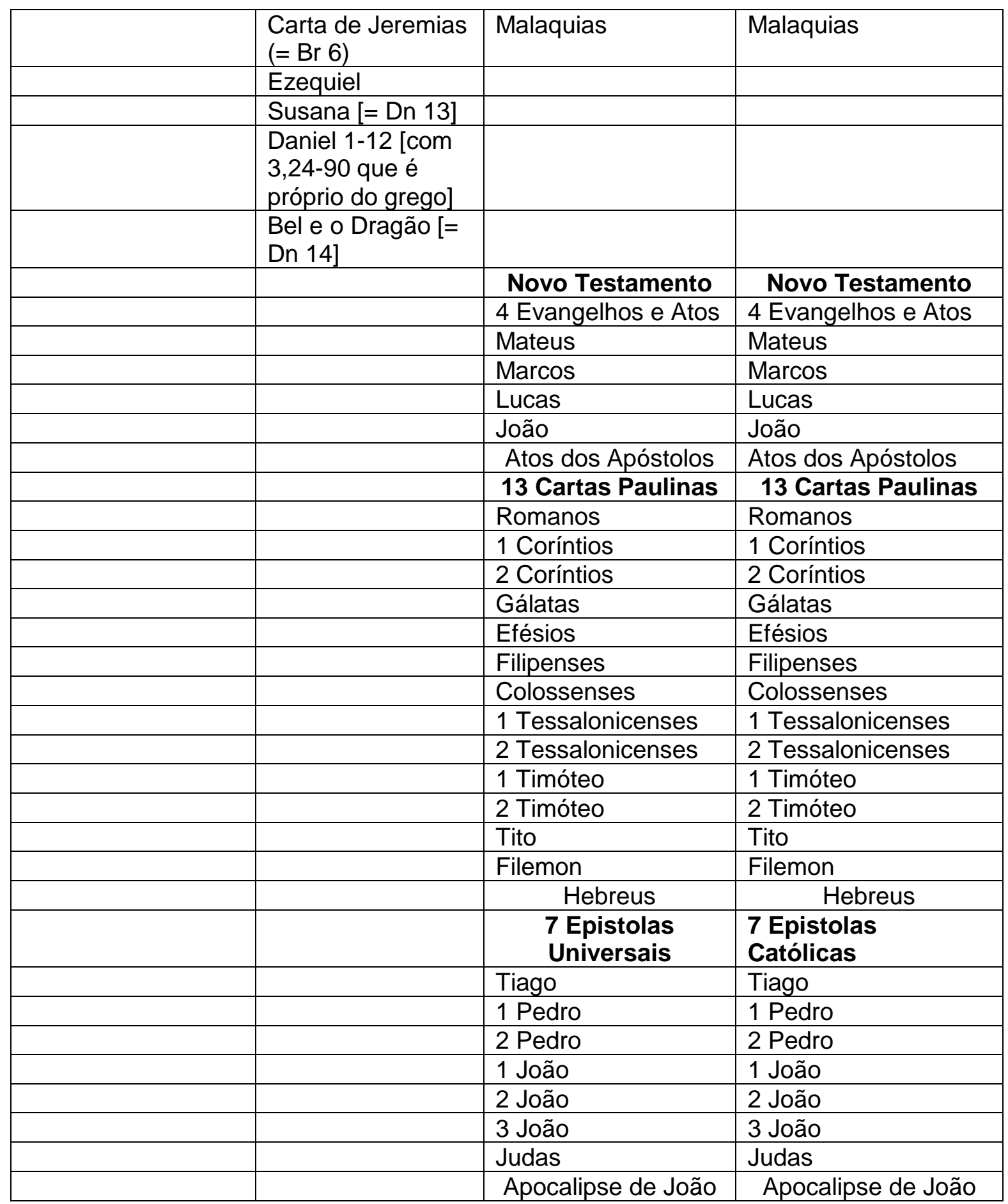

\section{Conclusão}

As Sagradas Escrituras judaico-cristãs encerram e contém a Palavra de Deus para judeus e cristãos, mesmo das mais diferentes correntes e formas de crer e seguir os ensinamentos nelas contidos. Elas contêm todos os livros considerados e aceitos como canônicos, ou seja, divinamente inspirados e revelados, isentos de "erros" no diz respeito à salvação, sejam eles livros [proto]canônicos ou [deutero]canônicos. Nelas não entraram os livros que não passaram pelos critérios da formação do Cânon Bíblico, a saber, os livros 
chamados apócrifos ou extracanônicos, tanto do AT como do NT, visto que não continham a fé da Igreja.

Escritos em épocas e por pessoas diferentes, ao longo de aproximadamente 1.000 anos de história e caminhada do Povo de Deus, os livros do AT e do NT encerram a revelação de Deus aos seres humanos e o encontro entre o divino e o humano. Um encontro que foi registrado em línguas, materiais e épocas diferentes, mas sempre com a mesma e única finalidade, conduzir o povo até o Messias e conduzir a Igreja pelos caminhos de Deus, em meio aos desafios de todos os tempos.

Passaram-se séculos desde que foram escritos os livros da Bíblia, tanto os judaicos (AT) como os cristãos (NT), mas eles continuam iluminando e alimentando a vida de muitas pessoas. Aliás, eles continuam sendo traduzidos de suas línguas originais (hebraico, aramaico e grego) para as mais diversas línguas modernas, sendo o livro mais traduzido, vendido e lido no mundo ainda hoje.

Enfim, as Escrituras judaico-cristãs são aquelas que são aceitas pelos cristãos católicos, ortodoxos, protestantes, pentecostais e neopentecostais, ainda que com diferenças no número de livros que formam o AT e o NT. Mas para todos e em cada tradição, os livros aceitos são Palavra de Deus e alimentam a vida de seus fiéis, seja na vida litúrgica, no culto, seja na vida pessoal, estudo e oração.

\section{Questões para ajudar na leitura e compreensão}

1) Em que sentido podemos falar de Bíblia é um livro judaico-cristão?

2) Quais são as línguas originais em que foram escritos os livros do AT e do NT e em quanto tempo foram escritos estes livros?

3) Quais os critérios para a aceitação ou não dos livros que entraram para a Bíblia e para os que ficaram fora dela?

4) Quantos livros tem cada Bíblia nas diferentes tradições: judaica e cristã, católica e protestante?

5) Em que sentido Deus e o ser humanos são autores da Bíblia?

6) O que se entende por inspiração, revelação e inerrância bíblicas?

\section{Referências Bibliográficas}

ARENS, Eduardo. A Bíblia sem mitos. Uma introdução crítica. São

Paulo: Paulus, 2012. 
FARIA, Jacir de Freitas. Bíblia Apócrifa, a outra face do cristianismo.

Cadernos Patrísticos, Vol. IV, n. 7, maio, p. 63-80, 2009.

FERNADES, Leonardo Agostini. A Bíblia e a sua mensagem, introdução à leitura e ao estudo da Bíblia, Editora PUC Rio, Rio de Janeiro, 2010.

GONZAGA, Waldecir. Compêndio do Cânon Bíblico. Listas bilíngues dos Catálogos Bíblicos. Antigo Testamento, Novo Testamento e Apócrifos. Rio de Janeiro, Petrópolis: Vozes; EdiPUC-Rio, 2019.

HARRINGTON, Wilfrid John. Chave para a Bíblia, a revelação, a promessa, a realização. São Paulo: Paulus, 2002.

MANNUCCI, Valerio. Bíblia, Palavra de Deus, Curso de introdução à Sagrada Escritura. São Paulo: Paulus, 2008.

MAZZAROLO, Isidoro. A Bíblia em suas mãos, Mazzarolo, Porto Alegre, 2000.

KONINGS, Johann. A Bíblia, sua origem e sua leitura, $7^{a}$ Edição Atualizada, Vozes, Petrópolis, 2011.

PONTIFÍCIA COMISSÃO BÍBLICA. A interpretação da Bíblia na Igreja. São Paulo: Paulinas, 1994. 